\title{
Letters
}

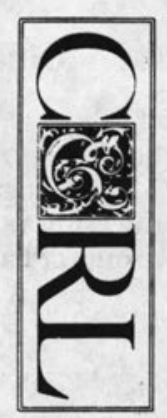

To the Editor:

In "Labor Unions or Professional Organizations: Which Have Our First Loyalty?" (CERL 53:331-41, July 1992), two reasons cited for nonmembership in unions are "unprofessional to be a union member" and "membership too costly."

Few librarians control fees, salaries, and policies or form partnerships in the manner of doctors or attorneys. Bargaining individually with a university to attain professional working conditions or salaries is ineffective. In two previous nonunion jobs I was paid barely half of what I currently earn for essentially the same duties. Is it professional to accept clerical wages? In the second job, the director told me that she wanted "good little bureaucrats, not professionals," and I was sometimes expected to engage in blatantly unethical conduct. I will never again accept a job without the protection or a union grievance procedure. As a department head, I appreciate unions because rules and procedures are clear and established.

"Membership too costly" is selfish and irresponsible. You can thank dues-paying union members for salary improvements, good benefit packages, access to sabbaticals and nineto ten-month contracts, etc. Is it really credible for people who benefit from unions but refuse to pay their fair share to complain that unions are somehow "unprofessional"?

"The graying of the profession" is a serious concern which may be exacerbated by union success. CSU and UC librarians are well paid by library standards, and the "golden shackle" discourages librarians who might benefit from a change of scenery. The answer to this problem and one way to attract young people to librarianship is to make professional level pay the national norm through collective bargaining. Having ALA pass a resolution won't do it. Empower yourself: join or form a union.

\section{JIM DWYER}

Head, Bibliographic Services Department

California State University, Chico

To the Editor:

I was delighted to read the article by Buchanan, Rupp-Serranno, and LaGrange (C\&RL 53:307-18, July 1992), entitled "The Effectiveness of a Projected Computerized Presentation ...." This has chronicled a testing process which is easily duplicated by any of us to test ourselves, and uses a technique, Show Partner F/X, which enables sophisticated presentation within a classroom. The article is well written and well researched, and contributes to the body of $\mathrm{BI}$ literature.

It also has a fatal flaw which tends to negate the results. Comparison is made between the "viewer" audience, and the "nonviewer" audience. Conclusions are reached which are interesting to all BI people. The flaw is that 66 percent of the "viewers" and only 30 percent of the "nonviewers" are sophisticated in library use by reason of their being nonfreshman. It is fairly obvious to any librarian that an upperclassman is bound to be somewhat more experienced in library use than a freshman. The writers know this and describe the reason for the mix on p. 313. The tables do not separate the two classes of students, although the data are there to be seen. Results should have been tabulated on the basis of experiences and nonexperiences, viewers and nonviewers. Had this been done, the results might have been somewhat different. Certainly the numbers of nonexperienced freshmen would have been much lower, and the results might have 
been less exciting and perhaps less trustworthy.

I am surprised that a refereed journal allowed this to slip through. I have written to the authors suggesting that they retabulate their results or retry the study with a larger group of true freshmen.

\section{VALERIE JACKSON FEINMAN \\ Coordinator of Library Instruction \\ Adelphi University Libraries}

To the Editor:

We in the Quaker Collection, Magill Library, Haverford College, have taken the idea of the internships mentioned by Otis A. Chadley in "Addressing Cultural Diversity in Academic and Research Libraries" (CERL 53:206-14, May 1992) one step earlier. Last year we began a summer internship for minority high school students in the Quaker Collection. We had three interns last year and will have two this year. The internships are intended to introduce the students to the various kinds of work that are done in an academic library and to provide extra summer help for us.

The four-week internship is structured so that the students spend time in informal lecture situations as well as working on constructive and/or educational tasks involving library materials. The lectures-really talks - are given by members of the library staff or college faculty who describe their roles in the library. Last year the educational project given to the interns involved their doing some investigation, using library resources, into the Harlem Renaissance. There are many very useful projects that the interns have helped and can help us with, including rehousing pamphlets and barcoding books.

It's too early to know if we have "created" librarians, and two people per year are admittedly not a massive number, but this level of intimacy allows us and the young people a pretty high-quality and satisfying library experience.
EMMA JONES LAPSANKSY
Curator, Quaker Collection
Magill Library
Haverford College 


\section{Be a PR Star! enter the}

1993

\section{JOHN COTTON DANA \\ LIBRARY PUBLIC RELATIONS AWARDS CONTEST}

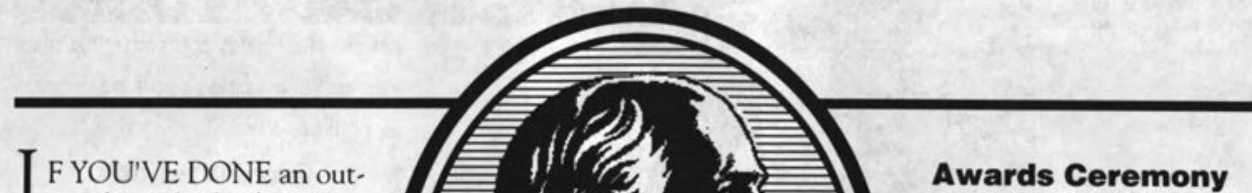

$I_{\text {standing job of making your }}$ community more aware of your library, the John Cotton Dana Library Public Relations Awards Contest can tell the world about your efforts.

Your entry will be considered among those from libraries of all types, sizes, and budgets. Entries are judged by a panel of your peers, and two types of awards are given.

\section{The John Cotton Dana Award}

This award is given for a library's total annual coordinated public relations program, including publicity, programs, advertising, publications, exhibits, special events, promotions, and audio-visual presentations.

\section{The Special Award}

The Special Award is given in recognition of a part of your public relations program-a fund-raising campaign, a series of adult or children's programs, or any other special project.

\section{Contest Dates}

Entries for the 1993 John Cotton Dana Library Public Relations Awards Contest can reflect any one of the following time frames:

- Calendar year 1992 (January-December)

- School Year 1991/92 (Fall-Spring)

- Special Project which ends in 1992.

The Deadline for entries is February 1, 1993.
Official award citations will be presented to contest winners at the 1993 annual conference of the American Library Association, at a reception hosted by The H.W. Wilson Company.

\section{Sponsorship}

The John Cotton Dana Library Public Relations Awards Contest is sponsored jointly by The H.W. Wilson Company and the Public Relations Section of the Library Administration and Management Association, a division of the American Library Association.

\section{To Enter}

To request an Information Packet containing contest entry forms, rules and regulations, questions and answers about the awards, a sample of the judges' evaluation form, names of the contest judges, and a list of previous winners, please write to: John Cotton Dana PR Awards Contest, The H.W. Wilson Company, 950 University Avenue, Bronx, New York 10452. 

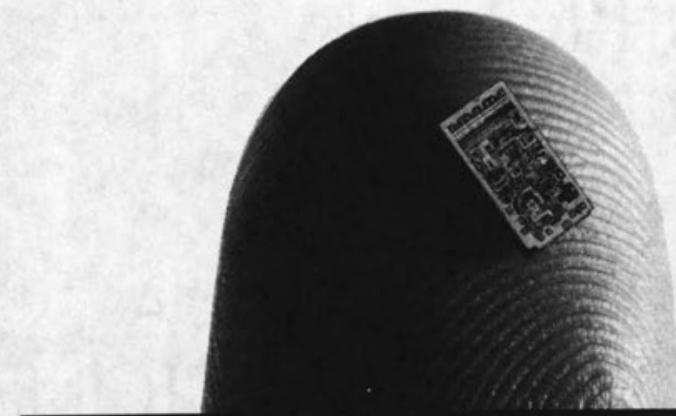

It's called a semiconductor chip mask work - the unique design, or fingerprint, of a computer chip. For U.S. high-tech firms, the creation of new, more advanced chip designs involves a huge investment. But for producers in some nations, computer chips are fair game - easily copied and enormously profitable.

The protection of Intellectual Property - such as chip mask works, patents and trademarks - is one of the most hothy debated topics worldwide. And it's

\section{YEARS IN RESEARCH, MILLIONS IN DEVELOPMENT}

\section{AND RIPPED OFF OVERNIGHT.}

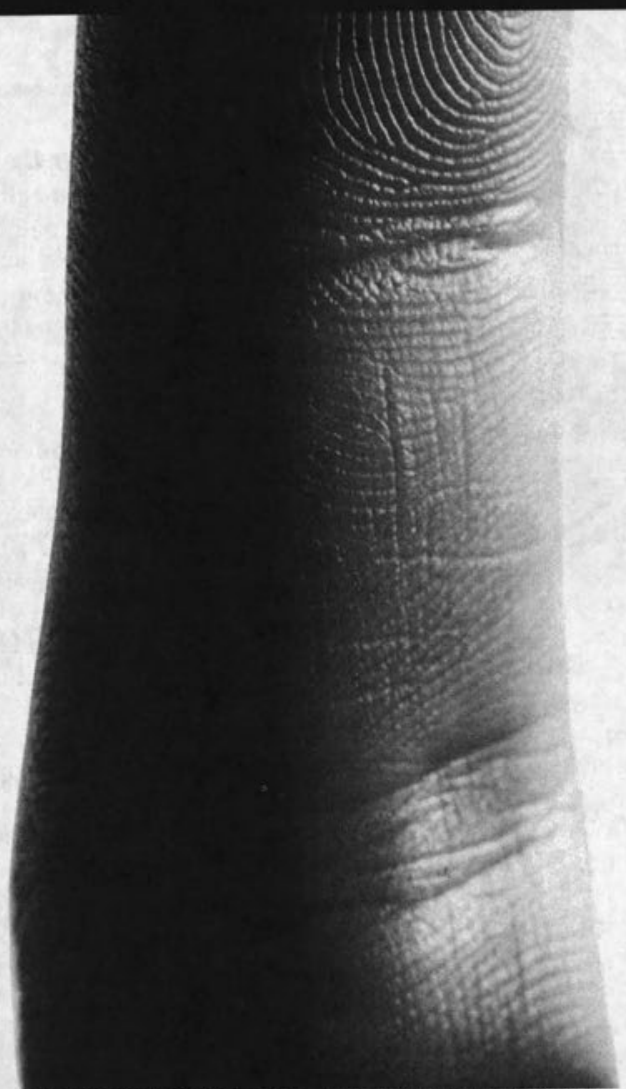

just one of thousands of important topics and questions you can explore quickly and thoroughly using PAIS International.

\section{Gain a global perspective}

The PAIS online and CD-ROM indexes provide easy access to over 350,000 hard-to-find journal articles, government documents, statistical directories, monographs, conference reports and more from all over the world. From trade to demographics, from public policy to international law, PAIS connects you to information you won't find anywhere else. Plus, PAIS provides an unrivaled global perspective via references to literature published in French, German, Italian, Spanish and Portuguese, as well as English.

Next time you have a tough question, don't get ripped-off. Get connected with PAIS.

Public Affoirs Informotion Service, Inc.

521 West 43rd Street, New York, NY 10036-4396

800-288PAIS, 212-736-6629 (in NYC) Fox 212-643-2848

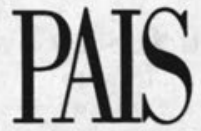

No one looks at the world like PAIS

In print: PAIS INTERNATIONAL IN PRINT - PAIS SUBJECT HEADINGS Online ThrOUgh: BRS - DATA-STAR - DIALOG - OCLL - RLG On CD.ROH: PAIS ON CD.ROM. PAIS INTERNATIONAL ON SILVER PLATTER OA Magnetic TaPE: CONTACT PAIS FOR INFORMATION 